\title{
Understanding the Relationship of Chronic Toxoplasma Gondii Infection and Schizophrenia
}

\author{
Taibur Rahman* and Hossain Uddin Shekhar \\ Department of Biochemistry and Molecular Biology, University of Dhaka, Bangladesh
}

Submission: December 10, 2018; Published: January 28, 2019

*Corresponding author: Taibur Rahman, Department of Biochemistry and Molecular Biology, University of Dhaka, Dhaka-1000, Bangladesh

\begin{abstract}
Toxoplasma gondii is a widely distributed neurotropic protozoan parasite that causes Toxoplasmosis in humans and animals. Approximately, 30-50\% populations are infected by this parasite world-wide. After acute infection, T. gondii undergoes developmental switching from its highly replicating tachyzoite stage to slowly replicating dormant bradyzoite stage preferentially in brain and skeletal muscle. Therefore, brain and skeletal muscle may act as a reservoir of T. gondii for persistent infection. In immunocompromised individual and developing fetus, T. gondii bradyzoite can reactivate and thereby can cause severe neurological disease for instance schizophrenia. In this mini-review, we have linked the association of chronic T. gondii infection with schizophrenia. This study would help scientist to perform in-depth research on discovering the mechanism of T. gondii infection in schizophrenia.
\end{abstract}

Keywords: Toxoplasma gondii; Brain; Schizophrenia; Immunocompromised patients; Fetus

\section{Introduction}

Toxoplasma gondii is an important neurotropic parasite that can infect any warm-blooded animals including humans and causes Toxoplasmosis. The infection rate varies from 10-90 $\%$ world-wide depending on environmental or socioeconomic factors and geographic locations [1]. Due to its wide-spread nature and infection capacity, T. gondii has both medical and veterinary importance. After acute infection in human and warm-blooded livestock animals, T. gondii accomplishes its asexual stages life cycle through stage conversion of the parasite from fast replicating tachyzoite to slow replicating dormant bradyzoite particularly in brain and skeletal muscle [2]. This stage differentiation of the parasite brain and skeletal muscle permit them for establishing lifelong persistent infection. It has to be stressed that human can become infected primarily by ingesting undercooked or raw meats of infected livestock animals or eating contaminated foods and water [3].

European multicenter case control study showed that 30-63 $\%$ of acute infections of pregnant women are due to consumption of infected undercooked meats [4]. In immunocompetent host, primary infection is generally mild with flu-like symptoms whereas T. gondii infection can cause life threatening problems in immunocompromised patients for instance AIDS, transplant and cancer [5]. Furthermore, congenital toxoplasmosis can interfere brain development in fetus [6] which may provide significant impact on severe neurological damage or even death of the fetus. Neurological disorder like schizophrenia is present in $\sim 1 \%$ people and ninth most common cause of disability over the world. The symptoms of the disease start from late teens to early adulthood, although the psychotic episodes can persist throughout the entire life of the patient. Till now, no single contributory driving force has been discovered; therefore, it is realistic only to explain some factors that were shown to be positively associated with schizophrenia. The well-known risk factors include: genetic predisposition, neurodevelopmental instability and environmental factors, including infectious agents $[7,8]$. In this study, we have deciphered the relationship of T. gondii infection and common neurological mental disorder schizophrenia.

\section{Impact of T. gondii on Schizophrenia}

Schizophrenia is a chronic and severe neurological disease that affect nearly one percent of adult population worldwide [9]. People with this disease suffer from hallucination (false perception), delusion (beliefs that conflict with reality), depression, apathy, poor social activities and lack of speech [10]. The exact etiological factor for Schizophrenia has not been identified yet but it is widely accepted that mostly genetic and environmental factors are prominent cause for pathogenesis of the disease [11]. Recent evidence suggests that infectious agents can act as a high-risk factor for onset of schizophrenia [12]. Previous studies have shown that infection with virus e. $g$ influenza, herpex simplex, rubella, polio and varicella zoster may contribute the development of schizophrenia [13]. Recently, T. gondii, an important neurotrophic protozoan parasite, has been 
identified as an important risk factor for developing symptoms of schizophrenia [14]. Thereafter a number studies has investigated the association of T. gondii and schizophrenia. Torry et al. [15] has summarized 38 studies of T. gondii and schizophrenia and confirmed the increased prevalence of anti- $T$. gondii antibodies in schizophrenia patients (odd ratio $2.73,95 \% \mathrm{CI}$ ). For instance, Hamidinejat and colleagues has shown that $57 \%$ patients with schizophrenia carry anti-T. gondii IgG antibodies compared to healthy controls [16]. Another study conducted by Mortensen and colleagues suggest that early infection of T. gondii in newborn may develop schizophrenia in later stage of life [17]. Contrary, some other studies has failed to reveal the association of T. gondii infection with schizophrenia [18-20]. Although the role of $T$. gondii infection in developing schizophrenia is controversial in very few studies, the above majority studies nevertheless, confirm the positive correlation of T. gondii infection and development of psychiatric disease like schizophrenia. However, the mechanism of how the parasite develops the disease is remaining unknown.

\section{Conclusion}

Despite having few controversial findings, it can be said that there is strong correlation of T. gondii infection and schizophrenia. The correlation between T. gondii and schizophrenia might be explained in the way as T. gondii develop bradyzoite tissue cysts and persist in brain of infected patient's life time, thereby the parasite may somehow modulate neurological parameter which may directly or indirectly involved in that process. Further research is needed to find out the exact factors that determine the relationship of T. gondii infection in schizophrenic patients.

\section{Acknowledgment}

We want to thank ministry of education, Bangladesh and department of Biochemistry and Molecular Biology, University of Dhaka for her cooperation.

\section{References}

1. Flegr J, Prandota J, Soviková M, Israili ZH (2014) Toxoplasmosis- A global threat. Correlation of latent toxoplasmosis with specific disease burden in a set of 88 countries. PLoS ONE 9(3): e90203.

2. Dubey JP, Lindsay DS, Speer CA (1998) Structures of Toxoplasma gondii Tachyzoites, Bradyzoites, and Sporozoites and Biology and Development of Tissue Cysts. Clin Microbiol Rev 11(2): 267-299.

3. Dubey JP (2004) Toxoplasmosis -a waterborne zoonosis. Veterinary Parasitology 126: 57-72.

4. Cook AJ, Gilbert RE, Buffolano W, Zufferey J, Petersen E, et al. (2000) Sources of toxoplasma infection in pregnant women: European multicentre case-control study. European Research Network on Congenital Toxoplasmosis. BMJ 321(7254): 142-147.

5. Montoya JG, Liesenfeld O (2004) Toxoplasmosis. The Lancet 363: 1965-1976.

6. Tenter AM, Heckeroth AR, Weiss LM (2000) Toxoplasma gondii: from animals to humans. Int J Parasitol 30(12-13): 1217-1258.

7. Henriquez SA, Brett R, Alexander J, Pratt J, Roberts CW (2009) Neuropsychiatric disease and Toxoplasma gondii infection. Neuroimmunomodulation 16(2): 122-133.

8. Torrey EF, Yolken RH (2003) Toxoplasma gondii and schizophrenia. Emerging Infectious Diseases 9(11): 1375-1380.

9. Janoutová J, Janácková P, Serý O, Zeman T, Ambroz P (2016) Epidemiology and risk factors of schizophrenia. Neuro Endocrinol Lett 37(1): 1-8.

10. Michele Sie (2011) Schizophrenia: clinical features and diagnosis. Clinical Pharmacist 3: 41-43.

11. Brown AS, Derkits EJ (2010) Prenatal infection and schizophrenia: a review of epidemiologic and translational studies. Am J Psychiatry 167(3): 261-280.

12. Arias I, Sorlozano A, Villegas E, de Dios Luna J, McKenney K, et al. (2012) Infectious agents associated with schizophrenia: a metaanalysis. Schizophr Res 136(1-3): 128-136.

13. Carter CJ (2009) Schizophrenia susceptibility genes directly implicated in the life cycles of pathogens: cytomegalovirus, influenza, herpes simplex, rubella, and Toxoplasma gondii. Schizophr Bull 35(6): 11631182.

14. RH Yolken, EF Torrey (2008) Are some cases of psychosis caused by microbial agents? A review of the evidence. Mol Psychiatry 13(5): 470479.

15. Torrey EF, Bartko JJ, Yolken RH (2012) Toxoplasma gondii and other risk factors for schizophrenia: an update. Schizophr Bull 38(3): 642647.

16. Hamidinejat H, Ghorbanpoor M, Hosseini H, Alavi SM, Nabavi L, et al. (2010) Toxoplasma gondii infection in first-episode and inpatient individuals with schizophrenia. Int J Infect Dis 14(11): e978-981.

17. Mortensen PB, Nørgaard-Pedersen B, Waltoft BL, Sørensen TL, Hougaard D, et al. (2007) Early infections of Toxoplasma gondii and the later development of schizophrenia. Schizophr Bull 33(3): 741-744.

18. De Witte LD, van Mierlo HC, Litjens M, Klein HC, Bahn S, et al. (2015) The association between antibodies to neurotropic pathogens and schizophrenia: a case-control study. NPJ Schizophr 1: 15041.

19. Karabulut N, Bilgic_S, G€urok MG, Karabo_ga F (2015) Is there any role of latent toxoplasmosis in schizophrenia disease? J Chin Med Assoc 78(9): 533-537.

20. Sugden K, Moffitt TE, Pinto L, Poulton R, Williams BS, et al. (2016) Is Toxoplasma gondii infection related to brain and behavior impirments in humans? Evidence from a population representative birth cohort. PLoS ONE 11(2): e0148435. 
(C) (i) This work is licensed under Creative Commons Attribution 4.0 Licens

BY DOI: 10.19080/AIBM.2019.12.555842

\section{Your next submission with Juniper Publishers} will reach you the below assets

- Quality Editorial service

- Swift Peer Review

- Reprints availability

- E-prints Service

- Manuscript Podcast for convenient understanding

- Global attainment for your research

- Manuscript accessibility in different formats ( Pdf, E-pub, Full Text, Audio)

- Unceasing customer service

Track the below URL for one-step submission https://juniperpublishers.com/online-submission.php 